\title{
The Onset of Action of Aqueous Extracts of Ceiba pentandra (Malvaceae) and Pseudocedrela kotschyi (Meliaceae) Plants with Potential Antipyretic Activity on Young Rats and their Interactions with Antimalaria Drugs (Artemisinin-based Combination)
}

\author{
Djadji ATL ${ }^{1 *}$, Effo KE ${ }^{1}$, Any-Grah-Aka $\mathbf{S}^{2}$, Kouakou $\mathrm{SL}^{1}$, Irie-N'Guessan $\mathbf{G}^{1}$, Kouakou-Siransy $\mathbf{G}^{1}$
}

${ }^{1}$ Laboratory Pharmacology, Clinical Pharmacy and Therapeutic: Laboratory of Pharmacology, UFR Pharmaceutical and Biological Sciences, Felix Houphouet-Boigny University, Ivory Coast

${ }^{2}$ Laboratory of Pharmacotechnic, Galenic Formulation and Pharmaceutical Legislation, Ivory Coast

*Corresponding author: Djadji ATL, Laboratory Pharmacology, Clinical Pharmacy, and Therapeutic: Laboratory of Pharmacology, UFR Pharmaceutical and Biological Sciences, Felix Houphouet-Boigny University, Ivory Coast, E-mail: djadji_thierry@yahoo.fr

Received date: November 03, 2018; Accepted date: November 28, 2018; Published date: December 04, 2018

Copyright: (C2018 Djadji ATL, et al. This is an open-access article distributed under the terms of the Creative Commons Attribution License, which permits unrestricted use, distribution, and reproduction in any medium, provided the original author and source are credited.

\begin{abstract}
Background: Several classical antipyretics are used to treat fever. But their harmful sides effects have led to the research of the others alternative based on medicine herbals. Rarely, studies are focused on the onset of action and assess the effects of Drugs Herbal interaction in vivo using experimental models. The main objective of this work is to assess potential antipyretic activities of two African plants (Ceiba pentandra and Pseudocedrela kotschyi concerning the onset of action and evaluate the effects of their association to the combination based on artemisinin (CTA).

Methods: Turpentine $2 \mathrm{ml} / \mathrm{kg}$, yeast brewers $20 \%$, boiled milk $1 \mathrm{ml} / \mathrm{kg}$ were used to induce fever in young rats. The crudes of the extract of Ceiba pentandra $200 \mathrm{mg} / \mathrm{kg} ; 400 \mathrm{mg} / \mathrm{kg}$ and Pseudocedrela kotschyi 100 and 150 $\mathrm{mg} / \mathrm{kg}$ were administered orally and the temperatures $\left({ }^{\circ} \mathrm{C}\right)$ were taken each 10 minutes. The Drugs-Herbal medicine interactions were also assessed (Extracts of our plants plus CTA). GraphPad Prism software version 7 was used to analyse the data. The difference was considered significant when $P<0.05$.
\end{abstract}

Results: Aqueous extract of the Ceiba pentandra and Pseudocedrela kotschyi quickly reduce the fever by reducing the onset time of action (10-30 minutes). P-value $<0.001$ but our study has shown pharmacodynamics interaction between CTA and Pseudocedrela. There may have some interaction between CTA and the natural compounds contained in these medicine plants that reduce their efficacy.

Conclusion: This present study showed the onset action of our two plants is between 10-30 minutes. Their association with CTA reduce the efficacy of extracts aqueous of leaves of Pseudocedrela kotschyi $150 \mathrm{mg} / \mathrm{kg}$ but no Ceiba pendantra $400 \mathrm{mg}$. They may be used as an alternative to classical drugs as antipyretics especially in children. But others studies may be done to assess the pharmacokinetic pharmacodynamics interactions with association based on artemisinin.

Keywords: Pseudocedrela kotschyi; Ceiba pentandra; Antipyretic; Onset of action; Plants

\section{Introduction}

Fever or pyrexia is one of the most causes of hospitalisation in Africa due to infectious diseases, especially in children. Unfortunately, conventional antipyretic therapeutic (Non-Steroid Anti-inflammatory Drugs) are harmful, expensive and possess several sides effects (Haemorrhage, gastric ulcer, hepatic toxicity, renal failure) [1]. Moreover, Fever normally results from the auxiliary effect of contamination, tissue harm, and aggravation; unite dismissal, threat or other unhealthy states, so it is for the most part connected with disorderly conduct, for example, depression, anorexia, tiredness, sleepiness, failure to think and hyperalgesia [1]. In children, because of their physiological vulnerability fevers can cause dramatic situations ranging from convulsions to loss of consciousness and even death.
Traditional drugs and herbal medicinal products can be defined as dietary supplements containing medicinal herbs or the herbal medicines traditionally used in phytotherapy for treating or preventing diseases [2]. According to the World Health Organization (WHO), more than $80 \%$ of the African population use plants for their health [3]. It is necessary because of public health to valorise this medicine plants that used for many Africans.

Several Africans plants are widely used as comestible and medicinal plants, such as Ceiba pentandra (Malvaceae) [4]; There are described for the treatment of many diseases, e.g., antidiabetic [5], antimicrobial [6], hypolipemiants [7] and Pseudocedrela kotschyi (Meliaceae); antiparasitary [8-10] antidiabetic [11] and others pathologies [12]. But, also, Ceiba pentandra and Pseudocedrela kotschyi are used to treat fever [13-15].

However, all the studies that assess potential antipyretic of medicinal herbs were focused on the effect between one to 6 hours 
generally in adult experimental models. Indeed, rapid delay of action may have contributed to the efficacy and quickly decrease the fewer particularly relieved temperature in children where high pyrexia my caused convulsion, seizure and tissues damage. Also, for the moral and ethical reasons, most of the time, studies in clinical and experimental are focused on adults and outcome parameters found are extrapolated to the young subjects. That cannot be always justified; because of young organs immaturities and their sensibility to drugs response. Pharmacokinetic parameters may be different between adults and young. Indeed, absorption is modified by age. Also, pharmacodynamics interactions have been less studied. However, the drugs can act by potentiation, antagonist, or synergy, i.e. the herbal medicines potentiate the pharmacological/toxicological action of synthetic drugs, or antagonistic, i.e. the herbal medicines reduce the efficacy of synthetic drugs further by complexations, enzymatic inhibitions [16]. So, as you all know absorption plays an important role in drug efficacy and treatment outcome.

Artemisinin-based combination (CAT) or especially Lumefantrine/ Artemether is widely used, in association with an antipyretic drug in the treatment of malaria in African especially in children, that it is one of the most cause of death of children.

The main objective of this work is to perform an antipyretic potential activity of two plants based on onset of action on rat young weight under 100 grams and assess pharmacodynamics interaction between Artemisinin-based combination and our medicinal herbal.

\section{Materials and Methods}

\section{Plant material}

Our Leaves of Ceiba pentandra (Malvaceae) and Pseudocedrela kotschyi (Meliaceae) were collected from Pakouabo (Bouaflé, Côte d'Ivoire). The plants were identified and authenticated by National Floristic Center (NFC) of University of Felix Houphouet Boigny of Abidjan.

\section{Chemical compounds and reagents}

Cow milk was purchased locally shepherd, Artemisinin-based combination (Coartem dispersible, Novartis Lumefantrin/ Artemether); paracetamol (Doliprane $500 \mathrm{mg}$ ) and yeast brewers (Arkopharma Laboratories) were by at the prived pharmacy. Turpentine bought from essential oils store.

\section{Laboratory animals used}

All experiments performed on the laboratory animals in this study followed the standard operating procedures. Hundred (100) Wistar rats (Rattus norgevicus) ( $<100 \mathrm{~g})$ were used for the study of antipyretic activity. All the animals were bred in the laboratory of Pharmacology of UFR Pharmaceutical and Biological Sciences of Felix HouphouetBoigny University. The rats were acclimated under standard conditions of temperature $24^{\circ} \mathrm{C} \pm 1^{\circ} \mathrm{C}$ with $75 \%$ humidity and light (approximately 12/24 light-dark cycle). All the animals were fasted for 24 hours but allowed water ad libitum were used for the experiment.

\section{Preparation of Ceiba pentandra and Pseudocedrela kotschyi leaves aqueous extracts}

Leaves of Ceiba pentandra and Pseudocedrela were dried in a dark ventilated room for 10 days. These parts were ground to fine powder using Restsch GM $300^{\mathrm{mix}}$ grinder mill. Extraction was carried out by cold maceration of $100 \mathrm{~g}$ of fine powder with $1000 \mathrm{ml}$ of distilled water for 24 hours. The macerate was successively filtered through the fabric, hydrophilic cotton, and finally Whatman paper. Subsequently, the filtrate was evaporated dried in a Memmert ${ }^{\mathrm{tw}}$ brand oven at $45^{\circ} \mathrm{C}$ for 3 days and the dark brown dried solids were stored in a refrigerator at $4^{\circ} \mathrm{C}$ for the pharmacological study.

\section{Hypothermic effect}

Before experimentation, rectal temperature of the rat was recorded by inserting a well-lubricated bulb of a thermometer in the rectum. Care was taken to insert it to the same depth each time (about $3 \mathrm{~cm}$ ). Effect of Ceiba pentandra $400 \mathrm{mg} / \mathrm{kg}$ and Pseudocedrela kotschyi 150 $\mathrm{mg} / \mathrm{kg}$ leaves aqueous extracts on the basal temperature of rats was assessed. The basal temperature was taken and extracts were given after, one-hour, rectal temperature was taken each hour until six.

\section{Evaluation of antipyretic activity}

Fever induced by essential oil of turpentine: Before fever induction, rats were weighed and their basal rectal temperature measured and recorded. The animal was fasted for 12 hours during the entire experimental period but was allowed access to water ad libitium. Steam distilled turpentine solution was used to induce fever. Rats were immediately administered subcutaneously turpentine $2 \mathrm{ml} / \mathrm{kg}$ in the dorsolateral region and the animal left for three hours [17]. After 3 hours, the $\mathrm{T}^{\circ}$ was again taken and a rise in rectal temperature of Wistar albino rats by $0.5^{\circ} \mathrm{C}$ after one hour was termed pyretic and proceeded to be used in the assay.

Fever induced by cow milk boiled: Before fever induction, rats were weighed and their basal rectal temperature measured and recorded. Milk was collected from local cow had been boiled. When the temperature of the boiled milk equilibrates to room temperature then rats were injected boiled milk at the dose of $0.5 \mathrm{ml} / \mathrm{kg}$ body weight, to induce pyrexia. Induction of fever was taken about six hours [18]. 8 groups of 6 rats each homogeneous in temperature: Group 1: Aqueous extract of Ceiba pentandra $200 \mathrm{mg} / \mathrm{kg}$; Group 2: Aqueous extract of Ceiba pentandra $400 \mathrm{mg} / \mathrm{kg}$, Group 3: Aqueous extract of Pseudocedrela kotschyi $100 \mathrm{mg} / \mathrm{kg}$ group 4: Aqueous extract of Pseudocedrela kotschyi $150 \mathrm{mg} / \mathrm{kg}$ Group 6 control group received $0.9 \% \mathrm{NaCl}$. Group 7 received paracetamol $100 \mathrm{mg} / \mathrm{kg}$. The rectal temperatures were then noted at 10 minutes (T10), 20 (T20), 30 (T30), 40(T40), 50 (T50), 60 (T60) using a digital thermometer TMP $812 \mathrm{RS}^{\mathrm{sm}}$ (Panlab) [15].

All the doses used were no toxic for the animal and literature data are shown that Ceiba pentandra is not toxic at the doses of $2 \mathrm{~g} / \mathrm{kg}$ [19] and for Pseudocedrela kotschyi DL50 by oral route is $1750 \mathrm{~g} / \mathrm{kg}$ [20].

We performed all experiments on the laboratory animals in this study followed the standard operating procedures.

\section{Pharmacodynamics and drugs herbal interactions}

To assess Drug-Herbal interactions, we used combination based on artemisinin (CTA) $5 \mathrm{mg} / \mathrm{kg}$ in distilled water orally in association with 
Citation: Djadji ATL, Effo KE, Any-Grah-Aka S, Kouakou SL, Irie-N'Guessan G, et al. (2018) The Onset of Action of Aqueous Extracts of Ceiba pentandra (Malvaceae) and Pseudocedrela kotschyi (Meliaceae) Plants with Potential Antipyretic Activity on Young Rats and their Interactions with Antimalaria Drugs (Artemisinin-based Combination). J Clin Exp Pharmacol 8: 257. doi:10.4172/2161-1459.1000257

Page 3 of 7

our extracts. Others groups of animals were used in the same conditions using suspension of $20 \%$ brewer's yeast at $1 \mathrm{ml}$ per $100 \mathrm{~g}$ body weight. Then, the rats fasted for food (free access to water). Seven (07) homogeneous groups of 6 rats each were made with the rats which showed an increase of at least $0.5^{\circ} \mathrm{C}$ in their rectal temperature. Homogeneity was obtained using the level of variation of hyperthermia.Group 8: Ceiba pentandra $400 \mathrm{mg} / \mathrm{kg}$; Group 9: CTA 5 $\mathrm{mg} / \mathrm{kg}$; Group 9: Ceiba pentandra+CTA $5 \mathrm{mg} / \mathrm{kg}$ group 10: Pseudocedrela kotschyi $150 \mathrm{mg} / \mathrm{kg}$. Group 11: Pseudocedrela kotschyi $150 \mathrm{mg} / \mathrm{kg}+\mathrm{CTA} 5 \mathrm{mg} / \mathrm{kg}$; Group 12: control group received $0.9 \% \mathrm{NaCl}$ group received paracetamol $100 \mathrm{mg} / \mathrm{kg}$. The rectal temperatures were then noted at 10 minutes (T10), 20 (T20), 30 (T30), 40 (T40), 50 (T50), 60 (T60) using a digital thermometer TMP 812 RS $^{\text {ma }}$ (Panlab) [15].

The research protocols were in accordance with the ethical rules and recommendation of the University of Felix Houphouet Boigny committee on the use and handling of laboratory animals. These principles are also in accordance with the National Research Council Guide for Care and Use of Laboratory Animals [21].

\section{Statistical analysis}

The rectal temperatures were recorded in GraphPad Prism software version 7 for statistical analysis. Descriptive statistics were expressed as the mean \pm standard error of the mean. One-way Analysis of Variance (ANOVA) was used to determine the significant difference between the means of different treatment groups followed by Dunnett post hoc tests for pairwise comparison among the various treatment groups. The mean activity of the two extracts was compared using unpaired student $\mathrm{t}$-test. The values of $\mathrm{p} \leq 0.05$ were considered significant. The data were presented in tables (Tables 1-7) and graphs/ figures (Figures $1-6)$.

\section{Results}

\section{Hypothermic activity}

Ceiba pentandra $400 \mathrm{mg} / \mathrm{kg}$ and Pseudocedrela kotschyi $150 \mathrm{mg} / \mathrm{kg}$ had not any impact on the normal temperature (Table 1). Extracts seem to have no action on the basal temperature at the doses used (Figure 1).

\begin{tabular}{|c|c|c|c|c|c|c|c|c|}
\hline \multirow{2}{*}{ Plants } & Temperature $\left({ }^{\circ} \mathrm{C}\right)$ & \multicolumn{5}{|c|}{ Time (Hours) } \\
\cline { 3 - 8 } & & $\mathbf{0}$ & $\mathbf{1}$ & $\mathbf{2}$ & $\mathbf{3}$ & $\mathbf{4}$ & $\mathbf{5}$ & $\mathbf{6}$ \\
\hline Ceiba pentandra 400 mg/kg & Mean \pm SD & $36.23 \pm 0.51$ & $36.17 \pm 0.40$ & $36.42 \pm 0.28$ & $36.38 \pm 0.36$ & $36.18 \pm 0.46$ & $36.5 \pm 0.56$ & $36.37 \pm 0.34$ \\
\hline $\begin{array}{c}\text { Pseudocedrela kotschyi } 150 \\
\mathrm{mg} / \mathrm{kg}\end{array}$ & Mean \pm SD & $36.23 \pm 0.51$ & $36.17 \pm 0.44$ & $36.42 \pm 0.28$ & $36.38 \pm 0.36$ & $36.18 \pm 0.46$ & $36.15 \pm 0.56$ & $36.37 \pm 0.34$ \\
\hline
\end{tabular}

Table 1: Effect of two extracts on the basal temperature.

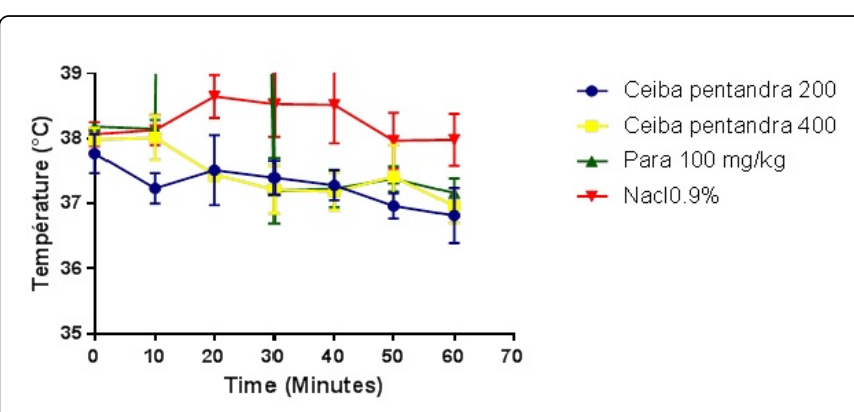

Figure 1: Onset action of Antipyretic activities of Ceiba pentandra.

Onset of action of potential antipyretic activities of Ceiba pentandra fever induced by turpentine (Table 2).

The antipyretic effect of our aqueous extracts has started between 20 and 30 minutes (Figure 2). So onset of action Ceiba pentandra comparatively to $\mathrm{NaCl} 0.9 \%$ at doses $200 \mathrm{mg}$ and $400 \mathrm{mg}$ are the same (Table 3).

\begin{tabular}{|c|c|c|c|c|c|c|c|}
\hline & 0 & 10 & 20 & 30 & 40 & 50 & 60 \\
\hline $\mathrm{NaCl} 0.9 \%$ vs Ceiba pentandra 200 mg/kg & * & **** & ns & $* * *$ & $* \star * \star$ & $* * *$ & $* * * *$ \\
\hline $\mathrm{NaCl} 0.9 \%$ vs Ceiba pentandra 400 mg $/ \mathrm{kg}$ & ns & ns & ns & $* * * *$ & $* * * *$ & * & $* * *$ \\
\hline
\end{tabular}

$\mathrm{NaCl} 0.9 \%$ vs Para $100 \mathrm{mg} / \mathrm{kg}$

\begin{tabular}{|l|l|l|l|l|l|l|} 
ns & ns & ns & $* * * *$ & $* * * *$ & $*$ & $* *$ \\
\hline
\end{tabular}

Table 2: Onset of action of Ceiba pentandra comparatively to $\mathrm{NaCl}$ $0.9 \%$ at doses $200 \mathrm{mg}$ and $400 \mathrm{mg} .{ }^{*} \mathrm{P}<0.05 ;{ }^{* *}<0.01 ;{ }^{* * *}<0.001$; ns $=$ no significance.

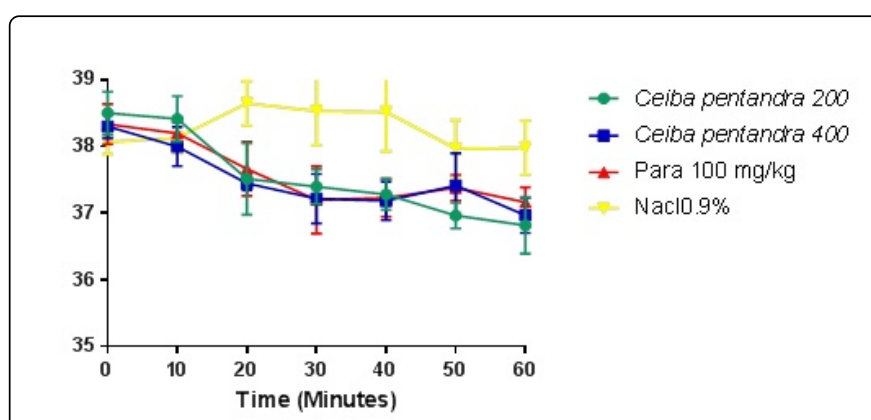

Figure 2: Onset action activities of potential antipyretic fever induced by boiled milk.

\begin{tabular}{|l|l|l|l|l|l|l|l|}
\hline & $\mathbf{0}$ & $\mathbf{1 0}$ & $\mathbf{2 0}$ & $\mathbf{3 0}$ & $\mathbf{4 0}$ & $\mathbf{5 0}$ & $\mathbf{6 0}$ \\
\hline $\mathrm{NaCl} 0.9 \%$ vs Ceiba pentandra $200 \mathrm{mg} / \mathrm{kg}$ & $*$ & $\mathrm{~ns}$ & $* * *$ & $* * *$ & $* * * *$ & $* * *$ & $* * *$ \\
\hline
\end{tabular}


Citation: Djadji ATL, Effo KE, Any-Grah-Aka S, Kouakou SL, Irie-N'Guessan G, et al. (2018) The Onset of Action of Aqueous Extracts of Ceiba pentandra (Malvaceae) and Pseudocedrela kotschyi (Meliaceae) Plants with Potential Antipyretic Activity on Young Rats and their Interactions with Antimalaria Drugs (Artemisinin-based Combination). J Clin Exp Pharmacol 8: 257. doi:10.4172/2161-1459.1000257

Page 4 of 7

\begin{tabular}{|l|l|l|l|l|l|l|l|}
\hline $\mathrm{NaCl} 0.9 \%$ vs Ceiba pentandra $400 \mathrm{mg} / \mathrm{kg}$ & $\mathrm{ns}$ & $\mathrm{ns}$ & $* * *$ & $* * *$ & $* * *$ & $*$ & $* * *$ \\
\hline $\mathrm{NaCl} 0.9 \%$ vs Para $100 \mathrm{mg} / \mathrm{kg}$ & $\mathrm{ns}$ & $\mathrm{ns}$ & $* * *$ & $* * * *$ & $* * * *$ & $*$ & $* *$ \\
\hline
\end{tabular}

Table 3: Onset of action of Ceiba Pentandra comparatively to $\mathrm{NaCl}$ $0.9 \%$ at doses $200 \mathrm{mg}$ and $400 \mathrm{mg} .{ }^{*} \mathrm{P}<0.05 ;{ }^{* *}<0.01 ;{ }^{* * *}<0.001$; ns $=$ no significance.

The antipyretic effect of our aqueous extracts has started between 10 and 20 minutes (Figure 3). So Onset of action of Ceiba Pentandra comparatively to $\mathrm{NaCl} 0.9 \%$ at doses $200 \mathrm{mg}$ and $400 \mathrm{mg}$ are the same (Table 4).

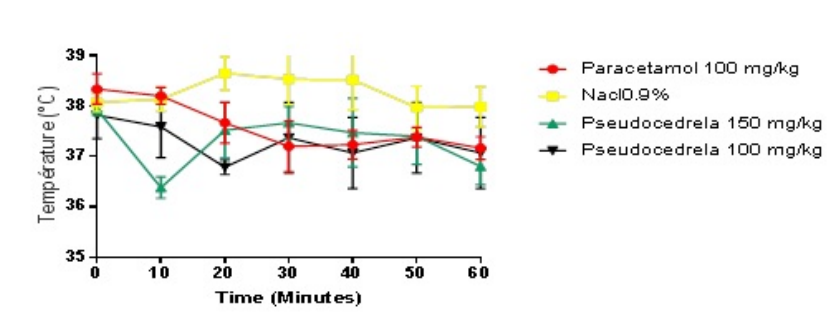

Figure 3: Onset of action potential antipyretic activities of aqueous extracts of Pseudocedrela Kotschyi.

\begin{tabular}{|l|l|l|l|l|l|l|l|}
\hline Time (min) & $\mathbf{0}$ & $\mathbf{1 0}$ & $\mathbf{2 0}$ & $\mathbf{3 0}$ & $\mathbf{4 0}$ & $\mathbf{5 0}$ & $\mathbf{6 0}$ \\
\hline $\begin{array}{l}\mathrm{NaCl} 0.9 \% \text { vs Paracetamol } 100 \\
\mathrm{mg} / \mathrm{kg}\end{array}$ & $\mathrm{ns}$ & $\mathrm{ns}$ & $* * *$ & $* * *$ & $* *$ & $\mathrm{~ns}$ & $*$ \\
\hline $\begin{array}{l}\mathrm{NaCl} 0.9 \% \text { vs Pseudocedrela } \\
150 \mathrm{mg} / \mathrm{kg}\end{array}$ & $\mathrm{ns}$ & $* * *$ & $* * *$ & $*$ & $*$ & $\mathrm{~ns}$ & $* * *$ \\
\hline $\begin{array}{l}\mathrm{NaCl} 0.9 \% \text { vs Pseudocedrela } \\
100 \mathrm{mg} / \mathrm{kg}\end{array}$ & $\mathrm{ns}$ & $*$ & $* * * *$ & $* *$ & $* *$ & $\mathrm{~ns}$ & $* *$ \\
\hline
\end{tabular}

Table 4: Onset of action potential antipyretic activities of aqueous extracts of Pseudocedrela Kotschyi. ${ }^{*} \mathrm{P}<0.05 ;{ }^{* *}<0.01 ;{ }^{* * *}<0.001$; ns $=$ no significance.

Time to have antipyretic action start at 10 minutes for the leaves of aqueous extracts at $150 \mathrm{mg} / \mathrm{kg}$ better than paracetamol $100 \mathrm{mg} / \mathrm{kg}$ (Figure 4 \& Table 5).

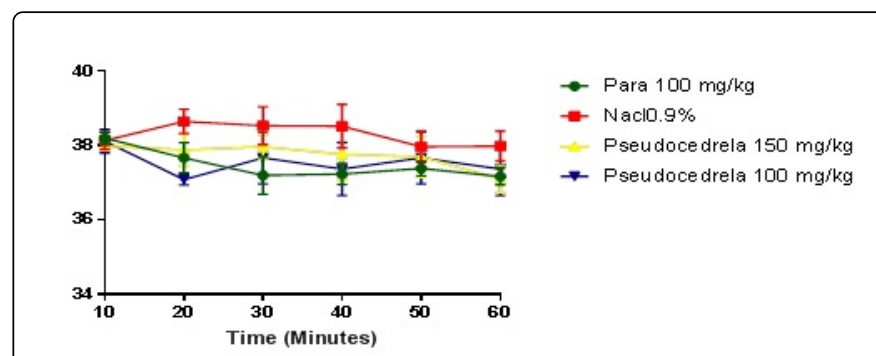

Figure 4: Onset of action of aqueous extracts of Pseudocedrela kotschyi fever induced by boiled milk.

\section{Drug-drug interaction induction due to yeast brewers}

Time to have antipyretic action start at 10-20 minutes for the leaves of aqueous extracts at $150 \mathrm{mg} / \mathrm{kg}$ fever induced by cow boiled milk (Figure 5 \& Table 6).

\begin{tabular}{|l|l|l|l|l|l|l|l|}
\hline & $\mathbf{0}$ & $\mathbf{1 0}$ & $\mathbf{2 0}$ & $\mathbf{3 0}$ & $\mathbf{4 0}$ & $\mathbf{5 0}$ & $\mathbf{6 0}$ \\
\hline $\mathrm{NaCl} 0.9 \%$ vs Paracetamol $100 \mathrm{mg} / \mathrm{kg}$ & $\mathrm{ns}$ & $\mathrm{ns}$ & $* * *$ & $* * *$ & $* *$ & $\mathrm{~ns}$ & $*$ \\
\hline $\mathrm{NaCl} 0.9 \%$ vs Pseudocedrela $150 \mathrm{mg} / \mathrm{kg}$ & $\mathrm{ns}$ & $\mathrm{ns}$ & $* *$ & $\mathrm{~ns}$ & $\mathrm{~ns}$ & $\mathrm{~ns}$ & $* *$ \\
\hline $\mathrm{NaCl} 0.9 \%$ vs Pseudocedrela $100 \mathrm{mg} / \mathrm{kg}$ & $\mathrm{ns}$ & $\mathrm{ns}$ & $* * *$ & $*$ & $* *$ & $\mathrm{~ns}$ & $\mathrm{~ns}$ \\
\hline
\end{tabular}

Table 5: Onset of action of aqueous extracts of Pseudocedrela Kotschyi fever induced by boiled milk. ${ }^{*} \mathrm{P}<0.05 ;{ }^{* *}<0.01$; ${ }^{* * *}<0.001$; ns $=$ no significance.

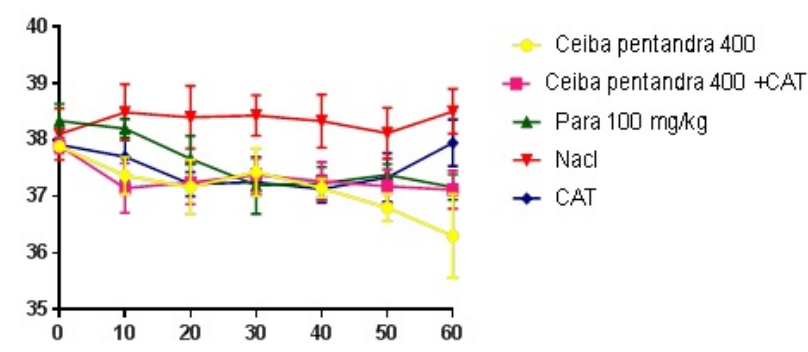

Figure 5: Interaction between Lumefantrine/Artemether 30/5 $\mathrm{mg} / \mathrm{kg}$ and Ceiba petendra $400 \mathrm{mg} / \mathrm{kg}$.

\begin{tabular}{|l|l|l|l|l|l|l|l|}
\hline & $\mathbf{0}$ & $\mathbf{1 0}$ & $\mathbf{2 0}$ & $\mathbf{3 0}$ & $\mathbf{4 0}$ & $\mathbf{5 0}$ & $\mathbf{6 0}$ \\
\hline $\begin{array}{l}\text { Ceiba pentandra } 400 \text { vs Ceiba } \\
\text { pentandra } 400+\mathrm{ns}\end{array}$ & $\mathrm{ns}$ & $\mathrm{ns}$ & $\mathrm{ns}$ & $\mathrm{ns}$ & $\mathrm{ns}$ & $*$ \\
\hline $\begin{array}{l}\text { Ceiba pentandra } 400 \text { vs Paracetamol } \\
150 \mathrm{mg} / \mathrm{kg}\end{array}$ & $*$ & $* *$ & $\mathrm{~ns}$ & $\mathrm{~ns}$ & $\mathrm{~ns}$ & $*$ & $*$ \\
\hline Ceiba pentandra 400 vs $\mathrm{NaCl}$ & $\mathrm{ns}$ & $* * *$ & $* * *$ & $* * *$ & $* * *$ & $* * *$ & $* * *$ \\
\hline Ceiba pentandra 400 vs CAT & $\mathrm{ns}$ & $\mathrm{ns}$ & $\mathrm{ns}$ & $\mathrm{ns}$ & $\mathrm{ns}$ & $\mathrm{ns}$ & $* * *$ \\
\hline $\begin{array}{l}\text { Ceiba pentandra } \\
\text { Paracetamol } 150 \mathrm{mg} / \mathrm{kg}\end{array}$ & $\mathrm{ns}$ & $* * *$ & $\mathrm{~ns}$ & $\mathrm{~ns}$ & $\mathrm{~ns}$ & $\mathrm{~ns}$ & $\mathrm{~ns}$ \\
\hline Ceiba pentandra $400+\mathrm{CAT}$ vs $\mathrm{NaCl}$ & $\mathrm{ns}$ & $* * *$ & $* * *$ & $* * *$ & $* * *$ & $* * *$ & $* * *$ \\
\hline Ceiba pentandra $400+\mathrm{CAT}$ vs CAT & $\mathrm{ns}$ & $\mathrm{ns}$ & $\mathrm{ns}$ & $\mathrm{ns}$ & $\mathrm{ns}$ & $\mathrm{ns}$ & $*$ \\
\hline Paracetamol $150 \mathrm{mg} / \mathrm{kg}$ vs $\mathrm{NaCl}$ & $\mathrm{ns}$ & $\mathrm{ns}$ & $*$ & $* * *$ & $* * *$ & $* *$ & $* * *$ \\
\hline Paracetamol $150 \mathrm{mg} / \mathrm{kg}$ vs CAT & $\mathrm{ns}$ & $\mathrm{ns}$ & $\mathrm{ns}$ & $\mathrm{ns}$ & $\mathrm{ns}$ & $\mathrm{ns}$ & $*$ \\
\hline NaCl vs CAT & $\mathrm{ns}$ & $*$ & $* * *$ & $* * *$ & $* * *$ & $* *$ & $\mathrm{~ns}$ \\
\hline
\end{tabular}

Table 6: Ceiba pentandra absorption. ${ }^{*} \mathrm{P}<0.05 ;{ }^{* *}<0.01 ;{ }^{* * *}<0.001$; ns $=$ no significance.

CAT does not affect Ceiba pentandra absorption. There is no difference between Ceiba pentandra 400 vs Ceiba pentandra 400+CAT. Also, Ceiba pentandra $400 \mathrm{vs}$. $\mathrm{NaCl}$ shows a significative difference in the fever. It seems that CAT does not affect Ceiba pentandra absorption (Figure 6 \& Table 7). 
Citation: Djadji ATL, Effo KE, Any-Grah-Aka S, Kouakou SL, Irie-N'Guessan G, et al. (2018) The Onset of Action of Aqueous Extracts of Ceiba pentandra (Malvaceae) and Pseudocedrela kotschyi (Meliaceae) Plants with Potential Antipyretic Activity on Young Rats and their Interactions with Antimalaria Drugs (Artemisinin-based Combination). J Clin Exp Pharmacol 8: 257. doi:10.4172/2161-1459.1000257

Page 5 of 7

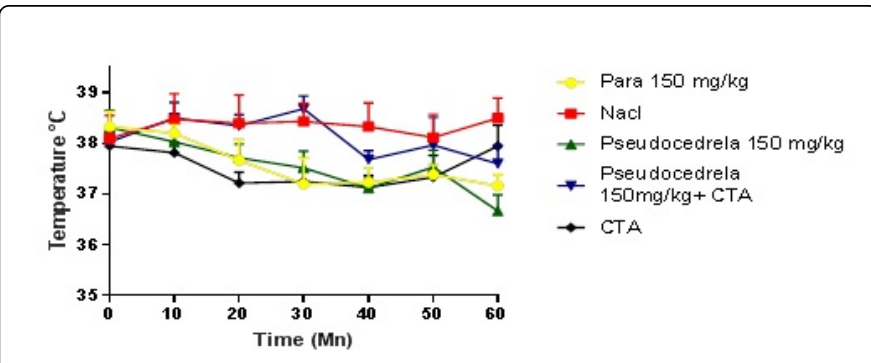

Figure 6: Interaction of Lumefantrine/Artemether $30 / 5 \mathrm{mg} / \mathrm{kg}$ with Pseudocedrela $150 \mathrm{mg} / \mathrm{kg}$.

\begin{tabular}{|l|l|l|l|l|l|l|l|}
\hline & $\mathbf{0}$ & $\mathbf{1 0}$ & $\mathbf{2 0}$ & $\mathbf{3 0}$ & $\mathbf{4 0}$ & $\mathbf{5 0}$ & $\mathbf{6 0}$ \\
\hline Paracetamol $150 \mathrm{mg} / \mathrm{kg}$ vs $\mathrm{NaCl}$ & $\mathrm{ns}$ & $\mathrm{ns}$ & $*$ & $* * *$ & $* * *$ & $*$ & $* * *$ \\
\hline $\begin{array}{l}\text { Paracetamol } 150 \mathrm{mg} / \mathrm{kg} \\
\text { Pseudocedrela } 150 \mathrm{mg} / \mathrm{kg}\end{array}$ & $\mathrm{ns}$ & $\mathrm{ns}$ & $\mathrm{ns}$ & $\mathrm{ns}$ & $\mathrm{ns}$ & $\mathrm{ns}$ & $\mathrm{ns}$ \\
\hline $\begin{array}{l}\text { Paracetamol } 150 \mathrm{mg} / \mathrm{kg} \\
\text { Pseudocedrela } 150 \mathrm{mg} / \mathrm{kg}+\mathrm{CTA}\end{array}$ & $\mathrm{ns}$ & $\mathrm{ns}$ & $*$ & $* * *$ & $\mathrm{~ns}$ & $\mathrm{~ns}$ & $\mathrm{~ns}$ \\
\hline Paracetamol $150 \mathrm{mg} / \mathrm{kg}$ vs CTA & $\mathrm{ns}$ & $\mathrm{ns}$ & $\mathrm{ns}$ & $\mathrm{ns}$ & $\mathrm{ns}$ & $\mathrm{ns}$ & $* *$ \\
\hline Nacl vs Pseudocedrela $150 \mathrm{mg} / \mathrm{kg}$ & $\mathrm{ns}$ & $\mathrm{ns}$ & $*$ & $* *$ & $* * *$ & $\mathrm{~ns}$ & $* * *$ \\
\hline $\begin{array}{l}\text { Nacl vs Pseudocedrela } 150 \mathrm{mg} / \mathrm{kg} \\
+ \text { +CTA }\end{array}$ & $\mathrm{ns}$ & $\mathrm{ns}$ & $\mathrm{ns}$ & $\mathrm{ns}$ & $* *$ & $\mathrm{~ns}$ & $* *$ \\
\hline $\begin{array}{l}\text { Nacl vs CTA } \\
\text { Pseudocedrela } 150 \mathrm{mg} / \mathrm{kg} \text { vs } \\
\text { Pseudocedrela } 150 \mathrm{mg} / \mathrm{kg}+\mathrm{ns}\end{array}$ & $\mathrm{ns}$ & $*$ & $* * *$ & $*$ & $\mathrm{~ns}$ & $* * *$ \\
\hline Pseudocedrela $150 \mathrm{mg} / \mathrm{kg}$ vs CTA & $\mathrm{ns}$ & $\mathrm{ns}$ & $\mathrm{ns}$ & $\mathrm{ns}$ & $\mathrm{ns}$ & $\mathrm{ns}$ & $* * *$ \\
\hline $\begin{array}{l}\text { Pseudocedrela } 150 \mathrm{mg} / \mathrm{kg}+\mathrm{CTA} \text { vs } \\
\text { CTA }\end{array}$ & $\mathrm{ns}$ & $*$ & $* * *$ & $* * *$ & $*$ & $\mathrm{~ns}$ & $\mathrm{~ns}$ \\
\hline
\end{tabular}

Table 7: Interaction of Lumefantrine/Artemether $30 / 5 \mathrm{mg} / \mathrm{kg}$ with Pseudocedrela $150 \mathrm{mg} / \mathrm{kg} .(\mathrm{P}<0.05){ }^{*} \mathrm{P}<0.05 ;{ }^{* *}<0.01 ;{ }^{* * *}<0.001 ; \mathrm{ns}=$ no significance.

The comparison of $\mathrm{NaCl}$ vs. Pseudocedrela kotschyi $150 \mathrm{mg} / \mathrm{kg}$ +CTA doesn't show any different, by $\mathrm{NaCl}$ vs. Pseudocedrela kotschyi $150 \mathrm{mg} / \mathrm{kg}$ gives a difference starting at 10 minutes. So, CTA leads the inhibition of the absorption of Pseudocedrela kotschyi.

\section{Discussion}

The harmful effects on the various organs of the body of antipyretic drugs of modern medicine such as paracetamol, aspirin, ibuprofen etc., have led recently to search herbal remedies with potent antipyretic activity [22]. So, this present study should have shown the interest of medicine plants against fever. Otherwise, the results of previous toxicity study have revealed that these plants might be considered as a broad non-toxic one. Indeed, traditional used and toxicological studies have revealed the safety and security of these two plants (Comestible and natural remedies) $[7,20,23]$.

First of all, our two extracts did not show any activity on the normal temperature of the rats. The extracts are not hypothermic (Table 1). These results confirm that these extracts act only on the endogenous mediators of fever. The aqueous extracts of these two plants could be used in the manufacture of drugs without the risk of lowering the temperature below normal values.

The antipyretic activity exhibited that both aqueous extracts of leaves possess a significant antipyretic effect in maintaining normal body temperature and reducing boiled milk induced and turpentine.

The Non-Steroidal Anti-inflammatory Drugs (NSAIDs) acts their antipyretic action mainly by inhibiting Prostaglandin E (PGE) production in the hypothalamus [24]. The hypothalamus works like a thermostat in many situations $[25,26]$. The febrile response involves innate immune system activation via Toll-like receptor 4 (TLR-4) leading to the production of pyrogenic cytokines such as; (IL)-1ß, IL-6, and tumour necrosis factor (TNF- $\alpha$ ). These pyrogenic cytokines act on an area of the brain known as the Organum vasculum of the laminae terminalis (OVLT) and eventually leading to the release of PGE2 via activation of cyclo-oxygenase 2 enzyme (COX-2) [25,27].

The study was designed to evaluate the antipyretic activity of aqueous extract of Ceiba pentandra and Pseudocedrela kotschyi on hyperthermia induced by turpentine, milk boiled and yeast brewers on experimental models. Several exogenous pyrogens can be used to induce fever in laboratory animals (lipopolysaccharides (LPS), E. coli, amphetamines, sulphur, brewer's yeast, and turpentine. [17,28]. Turpentine is a clear flammable liquid with a pungent odour and bitter taste, refined from resin pine. It is a mixture of organic compounds especially terpenes. Subcutaneous administration of turpentine is a well-established model for sterile inflammation. Turpentine causes tissue damage and induces acute phase response as well as fever [29]. However, Fever induced by boiled milk and yeast Brewers is like fever leads to infectious diseases $[30,31]$.

Total aqueous extract of Pseudocedrela kotschyi and Ceiba pentandra have reduced the elevated rectal temperature in rats and their effect are comparable to that of standard antipyretic drug paracetamol and more than $\mathrm{NaCl} 0.9 \%$ (Figures 2 and 3). The onsets of action of our two water extract between 10 to 30 minutes and are similar to the standard antipyretic drug. That reduction of rectal temperature of tested animals by both plants appears to be due to the presence of a single bioactive principle or mixture of compounds in them. Thus, herbal medicines contain a combination of pharmacologically active plant constituents that are claimed to work synergistically to produce an effect greater than the sum of the effects of the single constituents [32].

Pseudocedrela kotschyi and Ceiba pentandra demonstrated effective antipyretic activity as evident in the blocking of temperature elevation in the yeast, boiled milk, turpentine models. The antipyretic action of the extract may possibly be through inhibition of prostaglandin production, leading to suppression of elevated plasma levels [33]. The antipyretic activity observed can be attributed to the presence of steroids, tannins, alkaloids flavonoids, and polyphenols [32]. The present study, therefore, supports the claims of traditional medicine practitioners as an antipyretic remedy. However, to know the exact mechanism of action of our plants leaves extract further study with purified fractions/bioactive compounds are warranted. Those compounds act only on the endogen mediators of pyrexia.

Several factors influence the efficacy of drug therapy and it depends on related to a drug's pharmacokinetic and pharmacodynamic properties, which can be altered by differences in genetic polymorphisms, age, gender, circadian rhythms, intestinal bacteria, pathophysiological conditions, pharmaceutical dosage form, and 
Citation: Djadji ATL, Effo KE, Any-Grah-Aka S, Kouakou SL, Irie-N'Guessan G, et al. (2018) The Onset of Action of Aqueous Extracts of Ceiba pentandra (Malvaceae) and Pseudocedrela kotschyi (Meliaceae) Plants with Potential Antipyretic Activity on Young Rats and their Interactions with Antimalaria Drugs (Artemisinin-based Combination). J Clin Exp Pharmacol 8: 257. doi:10.4172/2161-1459.1000257

Page 6 of 7

xenobiotic. The co-administration of traditional drugs and herbal medicinal products may cause unexpected interactions. Drugs-herbal interactions may affect the efficacy of the medicinal plants. We assessed co-administration of CTA and our two plants on fever (Figures 4 and 5). In our study, it seems that there is not physicochemical complexation of the aqueous extracts of the leaves of Ceiba pentandra at $400 \mathrm{mg} / \mathrm{kg}$ and Lumefantrine/Artemether (Figure 4). The association between CAT and Ceiba pentandra decreased the fever. So we can say that CAT doesn't affect Ceiba pentandra effect on fever. The bioactive composition of their constituents may interact with others drugs took similarly Herb-drug pharmacodynamics interactions involve changes in the pharmacological effects of the drug through additive, synergistic or antagonistic actions. Indeed, any single herbal preparation contains several components, many of them having unknown biological activities; therefore, a herbal medicine can potentially mimic, increase, or reduce the effects of co-administered drugs through simultaneous effects on the same drug targets. Toxicity may occur if the effect of the drug in combination with the herbal medicine is enhanced synergistically or by additive effects [34].

Drugs-herbal interactions may affect the efficacy of the medicinal plants in many cases. In this work Assessment of co-administration of CTA and Aqueous extracts of leaves Pseudocedrela kotschyi at 150 $\mathrm{mg} / \mathrm{kg}$ on fever (Figure 5) has shown decreasing of activity of Pseudocedrela kotschyi. That means CTA may inhibit absorption of our plant in the conditions of the analysis by enhancing their onset of action. Because of his pharmacokinetic modification, Pseudocedrela kotschyi should not be associated with CAT. In the previous studies plants have reduced the efficacy of synthetic substances, indeed, Asphilia Africana, when used along with artemisinin, or chloroquine for malaria, has been reported to antagonize their effects [35]. Toxicity may occur if the effect of the drug in combination with the herbal medicine is enhanced synergistically or by additive effects. Also, many different side effects to herbs have been reported and recently reviewed including adverse events caused by herb-to-drug interactions [36] Since all herbal medicines are mixtures of more than one active ingredient, such combinations of many substances obviously increase the likelihood of interactions taking place. Hence, theoretically, the likelihood of herb-to-drug interactions is higher than drug-to-drug interactions, if only because synthetic drugs usually contain single chemical entities.

\section{Conclusion}

In conclusion, Ceiba pentandra and Pseudocedrela kotschyi do not have effects on the basal temperature. At the doses of $400 \mathrm{mg}$ and 150 mg extracts aqueous of the leaves respectively Ceiba pentandra and Pseudocedrela kotschyi. Their onset of action is between 10-30 minutes. Many others studies must be done to assess the pharmacokinetic interactions with association based on artemisinin.

\section{Conflicts of Interest}

The authors declare no conflicts of interest regarding this manuscript. The authors alone are responsible for the content and writing of the manuscript.

\section{References}

1. Sullivan EJ, Farrar HC (2011) Fever and antipyretic use in children. Pediatrics 127: 580-589.
2. Colalto C (2010) Herbal interactions on absorption of drugs: Mechanisms of action and clinical risk assessment. Pharmacol Res 62: 207-27.

3. Oliveira FCS, Barros RFM, Moita Neto JM (2010) Medicinal plants used in rural communities from Oeiras Municipality, in the semi-arid region of Piau\{í\} State (PI), Brazil. Rev Bras Plantas Med 12: 282-301.

4. Friday ET, James O, Olusegun O, Gabriel A (2011) Investigations on the nutritional and medicinal potentials of Ceiba pentandra leaf: A common vegetable in Nigeria. Int J Plant Physiol Biochem 3: 95-101.

5. Dzeufiet PD, Ohandja DY, Tedong L, Asongalem EA, Dimo T, et al. (2007) Antidiabetic effect of Ceiba pentandra extract on streptozo-tocininduced non-insulin-dependent diabetic (NIDDM) rats. African J Tradit 4: $47-54$.

6. Doughari JH, Ioryue AS (2009) Antimicrobial activity of stem bark extracts of Ceiba pentandra. Pharmacol online 1: 1333-1340.

7. Amol Patil PA, Thakurdesai, Shrikant Pawar, Soni K (2012) Evaluation of ethanolic leaf extract of Ceiba pentandra for anti-obesity and hypolipidaemic activity in cafeteria diet (CD) treated wistar albino rats. Int J Pharm Sci Res 3: 2664-2668.

8. Ahua KM, Loset JR, Loset KN, Diallo D, Mauel J (2007) Antileishmanial activities associated with plants used in the Malian traditional medicine. J Ethnopharmacol 110: 99-104.

9. Kone WM, Atindehou KK, Dossahoua T, Betschart B (2005) Anthelmintic activity of medicinal plants used in northern Côte d'Ivoire against intestinal helminthiasis. Pharm Biol 43: 72-78.

10. Sidjui LS, Nganso OD, Toghueo MK, Wakeu NK, Dameue JT, et al. (2018) Kostchyienones A and B, new antiplasmodial and cytotoxicity of limonoids from the roots of Pseudocedrela kotschyi (Schweinf.) Harms. Zeitschrift fur Naturforsch C. J Biosci 73: 95-163.

11. Bothon FT, Debiton E, Avlessi F, Forestier C, Teulade JC, et al. (2013) In vitro biological effects of two anti-diabetic medicinal plants used in Benin as folk medicine. BMC Complement Altern Med 13: 51.

12. Kassim OO, Copeland RL, Kenguele HM, Nekhai S, Ako-Nai KA, et al. (2015) Antiproliferative activities of fagara xanthoxyloides and pseudocedrela kotschyi against prostate cancer cell lines. Anticancer Res 35: $1453-1458$

13. Saptarini NM, Deswati DA (2015) The antipyretic activity of leaves extract of ceiba pentandra better than gossypium arboretum. J Appl Pharm Sci 5: 118-121.

14. Kallangouda RA, Amol SS (2012) Analgesic and antipyretic effects of Ceiba pentandra L. Seed extracts. Int J Pharm Res 3: 48-51.

15. Essien AD, Essiet GA, David-Oku E, Akoudor GC, Akpan JL, et al. (2013) Evaluation of antipyretic potential of pseudocedrela kotschyi Schweint. Harms (Meliaceae) Eur J Med Plants 3: 105-113.

16. Thomford NE, Awortwe C, Dzobo K, Adu F, Chopera D, et al. (2016) Inhibition of CYP2B6 by medicinal plant extracts: Implication for use of efavirenz and nevirapine based highly active anti-retroviral therapy (HAART) in resource-limited settings. Molecules 21: E211.

17. Tung K, Fujita H, Yamashita Y, Takagi Y (2006) Effects of turpentine induced fever during the enamel formation of rat incisor. Arch Oral Biol 51: 464-470.

18. Sankar Anand R, Subhadra Devi V, Arunprasath B, Subageetha A (2011) Boiled milk induced pyrexia in rabbits- antipyretic activity vernonia cinerea roots. Int J Pharm Sci Res 2: 127-131.

19. Gandhare B, Kavimani S, Rajkapoor B (2013) Acute and subacute toxicity study of methanolic extract of ceiba pentandra (Linn.) Gaertn. on Rats. J Sci Res 5: 315-324.

20. Kabiru A, Muhammad DN, Bello MB, Akpojo AJ, Fei YM, et al. A 28- day oral toxicity study of pseudocedrela kotschyi methanol extract in spraguedawley rats. Eur J Med Plants 10: 1-11.

21. National Research Council (US) Committee, guide for the care and use of laboratory animals, 8th Ed,. 2011.

22. Hunter LJ, Wood DM, Dargan PI (2011) The patterns of toxicity and management of acute nonsteroidal anti-inflammatory drug (NSAID) overdose. Open Access Emerg Med 3: 39-48. 
Citation: Djadji ATL, Effo KE, Any-Grah-Aka S, Kouakou SL, Irie-N'Guessan G, et al. (2018) The Onset of Action of Aqueous Extracts of Ceiba pentandra (Malvaceae) and Pseudocedrela kotschyi (Meliaceae) Plants with Potential Antipyretic Activity on Young Rats and their Interactions with Antimalaria Drugs (Artemisinin-based Combination). J Clin Exp Pharmacol 8: 257. doi:10.4172/2161-1459.1000257

Page 7 of 7

23. Sarkiyayi S, Ibrahim S, Abubakar MS (2009) Toxicological studies of Ceiba pentandra Linn. African J Biochem Res 3: 279-281.

24. Aronoff DM, Neilson EG (2001) Antipyretic mechanism of action and clinical uses of in fever suppression. Am J Med 111: 304-315.

25. Boulant JA (2000) Role of the preoptic-anterior hypothalamus in thermoregulation and fever. Clin Infect Dis 31: S157-161.

26. Dalal S, Zhukovsky DS (2006) Pathophysiology, and management of fever. J Support Oncol 4: 9-16.

27. Vasundra DP, Priya DS (2013) Antipyretic Activity of ethanol, and aqueous extract of root of asparagus racemosus in yeast induced pyrexia. Asian J Pharm Clin Res 6: 190-193.

28. Kozak W, Kluger MJ, Soszynski D, Conn CA, Rudolph K (1998) IL-6 and IL-1 $\beta$ in fever. Studies using cytokine-deficient (knockout) mice. Ann N Y Acad Sci 856: 33-47.

29. Tarkang PA, Okalebo FA, Siminyu JD, Ngugi WN, Mwaura AM, et al. (2015) Pharmacological evidence for the folk use of Nefang: Antipyretic, anti-inflammatory and antinociceptive activities of its constituent plants. BMC Complement Altern Med 15: 174.
30. Effo KE, Siransy KG, Nguessan GI, Sawadogo RW, Dally IL, et al. (2013) Acute toxicity and antipyretic activities of a methanolic extract of Alchornea cordifolia leaves. J Pharm Pharmacol 4: 1-6.

31. Ernst BK, Pittler MH, Wider B, Oxford Handbook of Complementary Medicine. Oxford, Oxford University Press. 2008.

32. Ogbiti VM, Akindele AJ, Adeyemi OO (2017) Analgesic, antiinflammatory, and antipyretic activities of hydroethanolic stem bark extract of albizia glaberrima. J Herbs Spices Med Plants 23: 44-67.

33. Izzo AA, Ernst E (2009) Interactions between herbal medicines and prescribed drugs: An updated systematic review. Drugs 69: 1777-1798.

34. Abii TA, Onuoha EN (2011) The chemical constituents of the leaf of Aspilia africana as a scientific backing to its tradomedical potentials. Agri J 6: 28-30.

35. Zhou SF, Zhou ZW, Li CG, Chen X, Yu X, et al. (2007) Identification of drugs that interact with herbs in drug development. Drug Discov Today 12: 664-673.

36. Kennedy DA, Seely D (2010) Clinically based evidence of drug-herb interactions: a systematic review. Expert Opin Drug Saf 9: 79-124. 